\title{
Care-giving Burden and Quality of Life in Diabetic Foot Patients' Care Givers
}

\author{
Diyabetik Ayaklı Hastaların Bakım Verenlerinde Bakım Veren Yükü ve Yaşam Kalitesi \\ (D) Ece Yazla ${ }^{1}$, Mehmet Emrah Karadere ${ }^{1}$, (D Özlem Terzi ${ }^{2}$, (Dete Dolapçı ${ }^{3}$, (D) Ahmet Çınar Yastı ${ }^{3}$ \\ ${ }^{1}$ Hitit University Medical School, Department of Psychiatry, Corum, Turkey \\ 219 Mayıs University, Department of Public Health, Samsun, Turkey \\ ${ }^{3}$ Hitit University Medical School, Department of Surgery, Corum, Turkey
}

\section{ÖZET}

Giriş: Bakım veren yükü, yaşlı, kronik hastalığı veya yetersizliği olan bireye bakım veren kişinin yük altına girmesi olarak tanımlanmaktadır. Bu yükün algılanma düzeylerini çeşitli kişisel ve hastalığa ait özelliklerin etkilediği bilinmektedir. Dâhili ve psikiyatrik hastalıkları olan hastaların bakım verenlerinin yüklerinin karşılaştırıldığı çalışmalarda psikiyatri grubunda bakım veren yükünün anlamlı yüksekliği bildirilmiştir. Bu çalışmamızda, diyabetik ayaklı hastaların bakım verenlerini, yük düzeyi açısından psikotik hastaların ve kontrol grubu kabul ettiğimiz inguinal herni ameliyatı geçiren hastaların bakım verenlerinin yük düzeyleri ile karşılaştırmayı ve bakım veren yükü ile ilişkili özellikleri araştırmayı amaçladık.

Yöntem: Hastanemizde yatarak tedavi alan 30 diyabetik ayak ve 30 inguinal herni tanılı, Çorum Toplum Ruh Sağlı̆̆ı Merkezi (TRSM)'nde psikotik bozukluk tanısı ile kayıtlı 30 hastanın bakım verenleri dâhil edildi. Gönüllülerin Zarit Bakıcı Yükü, Beck Depresyon, Beck Anksiyete, Hastane Anksiyete ve Depresyon (HAD) ve Kısa Form-36 (SF-36) ölçeklerini doldurmaları sağlandı.

Bulgular: Diyabetik ayaklı grubun bakım verenlerinin çoğunluğunun çalışmayan kadınlardan oluştuğu gözlendi. Bakım veren yükü düzeyleri psikoz grubununkinden farksız, kontrol grubundan anlamlı yüksek bulundu $(\mathrm{p}<0,001)$. Kontrol ve psikoz grubuna kıyasla, diyabetik ayak grubunda depresyon ve anksiyete ölçekleri anlamlı yüksek, bazı yaşam kalitesi alt ölçeklerinin puanları ise anlamlı düşük saptandı. Sadece, diyabetik ayaklı grupta bakım verme süresi yük ile ilişkili bulundu $(r=0,421, p=0,020)$.

Sonuç: Diyabetik ayaklılara bakım verenler, sosyal hayattan daha fazla izole kalmaktadırlar. Muhtemelen bakıma ihtiyacı olan bir yaşlı ile yaşamak zorunda kalmaları buna neden olmaktadır. Her ne sebeple olursa olsun, diyabetik ayaklı hastalara bakım verenlerde anksiyete ve depresyon düzeyleri yüksek, hayat kalitesi azalmış ve yük düzeyleri de psikotik grup kadar yüksek bulunmuştur. Bu nedenle, bakım verenlerin fiziki ve ruhsal sağlılarının korunması anlamında, dikkatle izlenmeleri ve gereğinde destek tedavilerinin başlanması uygun olacaktır.

Anahtar Kelimeler: Bakım veren yükü; diyabetik ayak; hayat kalitesi

\begin{abstract}
Introduction: The burden of care-giving is defined as the burden sustained by an individual who is giving care to an elderly, chronically ill or incapacitated person; the levels of perception of the burden are known to be affected by various personal and disease-related characteristics. Studies that compare the burden of internal patients' caregivers with psychiatric patients' caregivers, reported higher caregiving burden for caregivers of psychiatric patients. In this study, it was aimed to compare the levels of the caregiving burden of those caring for patients with diabetic foot with care-givers of psychotic patients. Caregivers of those with inguinal hernia were designated as the control group to determine the characteristics that are related to the care-giving burden.

Methods: The study was comprised of care-givers of 30 hospital in-patients with diabetic foot, 30 in-patients with inguinal hernia, and care givers of 30 patients with a recorded diagnosis of psychotic disorder at Çorum Community Mental Health Centre. The evaluation was made from voluntary completion of the Zarit Burden Interview Form and the Beck Depression, Beck Anxiety, Hospital Anxiety and Depression (HAD) and Short Form-36 (SF-36) scales.

Results: The caregivers of the diabetic foot group were found to be mostly non-working females. No difference was found between the burden levels of psychotic and diabetic patient groups but the burden level of caregivers of psychotic patients was determined to be significantly higher than the control group $(\mathrm{p}<0.001)$. In comparison with those of the control and psychotic group, the depression and anxiety scales of the diabetic foot group were signficantly high and some points of the quality of life scales were determined to be significantly low. A correlation between the duration of care-giving and the burden was only determined in the diabetic foot group $(\mathrm{r}=0.421, \mathrm{p}=0.020)$.

Conclusion: Care-givers of diabetic foot patients remained more socially isolated. This was probably due to having to live with an elderly person requiring care. For various reasons, care-givers of diabetic foot patients were found to have high levels of anxiety and depression, low quality of life, and burden levels as high as those of the psychotic group. Therefore, in the context of protecting the physical and emotional health of care-givers, careful monitoring and when necessary, supportive treatment would be appropriate.

Keywords: Care-giving burden; diabetic foot; quality of life
\end{abstract}

Başvuru / Submission: Eylül / Sept 03, 2017

Kabul / Acceptance: Aralık / Dec 21, 2017

Yazışma / Correspondence: Ece Yazla, Hitit University Erol Olçok Education and Research Hospital, Çepni Mahallesi, İnönü Cd.

No:176, 19040 Çorum Merkez/Çorum

E-Mail: eceyazla@yahoo.com 


\section{INTRODUCTION}

Medical advances in the last century have enabled the treatment of many diseases and delayed mortality for those who can not be treated. This has caused an increase in the number of patients requiring care and an increased need for care-givers. A care-giver is defined as a person providing physical, psychological, and socio-economic support (without payment) to an individual with a chronic disease ${ }^{1}$. As the responsibilities of care increase, there is inevitably a conflict with the care-giver's work, family and social life; thus, with the increase of problems in a caregiver's life, a care-giving burden can occur ${ }^{2}$.

The burden of caregiving is defined as the burden sustained by an individual, the feeling of being under pressure, or difficulties experienced during the period of giving care to an elderly, chronically ill, or incapacitated person ${ }^{3}$. The levels of perception of the burden are known to be affected by various personal and disease-related characteristics. The characteristics related to the caregiver include age, ethnicity, gender, closeness to the patient, whether or not the care is provided willingly, educational level, economic level, whether or not the caregiver has an illness, coping skills, beliefs, social support, and the care requirements ${ }^{4}$. The function of caregiving can become more burdensome depending on the characteristics of the disease. The burden experienced by the caregiver leads to negative outcomes, such as depression, anxiety, burnout, poor physical health, social isolation and economic difficulties ${ }^{1}$. The care requirements differ according to various internal and psychiatric conditions. Significant differences have been found in studies comparing the burdens of internal patients caregivers with psychiatric patients care-givers ${ }^{5,6}$.

In this clinical study, it was aimed to investigate the burden of caregivers of patients with diabetic foot and chronic psychiatric disorder compare the levels of the caregiving burden in those who care for chronic physical and psychiatric patients and investigate the characteristics related to the caregiving burden in both groups. To be able to evaluate chronic psychiatric diseases, the caregivers of patients diagnosed with schizophrenia were included as much research has been previosly done with these patients and their burden of caregiving has been determined to be high ${ }^{7-9}$. To investigate the caregiver burden in chronic physical diseases, the caregivers of patients with diabetic foot were included, although there has been limited research with these patients, as their burden of care is known to be severe ${ }^{10}$. The a control group consisted of the care-givers of patients operated on for inguinal hernia who did not require long-term care and had no chronic diseases.

\section{METHODS}

This study was cross-sectional and observational. The ethical approval was given by Ankara Numune Training and Research Hospital before beginning the study. Volunteers read and signed the informed consent forms before participating in the study.

The study included the care-givers of patients registered with a diagnosis of psychotic disorder at Çorum Community Mental Health Centre and the care-givers of patients admitted to our hospital with a diagnosis of inguinal hernia or diabetic foot. All participants met the inclusion and exclusion criteria.

Inclusion criteria were defined as being between 18 and 65 years of age, willing to participate in the study, no mental illness which would prevent true evaluation (mental retardation, psychotic disorder, dementia etc), being able to read and understand the evaluation scales, having a level of literacy enabling them to complete the form themselves and signing the informed consent form freely and willingly. Those aged below 18 years or over 65 years and those who did not sign the informed consent form were excluded from the study. A total of 30 care-givers of patients with psychotic disorders, 30 care-givers of patients with diabetic foot and 30 care-givers of patients with inguinal hernia were included in the study, which took place between 1 May 2014 and 30 June 2014.

Informed consent was obtained from all participants of their own free will. The care-giver's age, gender, educational level, monthly income, relationship to the patient, duration of care (years), hours spent together per day, and existence of any diagnosed physical or psychological disease, along with the age, gender and education level of the person receiving the care were recorded with a sociodemographic data form.

To measure the level of the care-givers' burden, the Zarit Burden Interview form was completed. The Beck Depression, Beck Anxiety, Hospital Anxiety and Depression (HAD) scales were used to measure the depression and anxiety levels and the Short Form-36 (SF-36) was used to evaluate quality of life. The forms were completed by the care-givers themselves, who could consult the attendant clinician on any questions which they did not understand. The forms were completed by the care-givers in the hospital setting, either in the mental health centre or in the general surgery department. 
As the scales used in this study have not been studied for validity and reliability in pediatric or geriatric age groups, only care-givers aged 18-65 were included in the study. Pregnant or breastfeeding females were not included in the study to avoid the possibility of incorrect findings showing high depression and anxiety scores due to possible anxiety of childbirth or postnatal depression.

\section{The scales administered to the care-givers}

The Zarit Burden Interview Form: It was developed by Zarit, et al. to subjectively evaluate the level of the burden of care in chronic disorders ${ }^{11}$. The scale has been tested for validity and reliability in Turkish ${ }^{12}$. The form consists of 19 statements with a 5-point Likert response for each. Administration is easy as it is easily understood. There is no cutoff point. Higher total points demonstrate high level of problems experienced.

The Beck Depression Inventory (Beck-D): The original measurement scale form was developed by Beck, et al. ${ }^{13}$. It has been tested for validity and reliability in Turkish ${ }^{14}$. It is a self-evaluation form to measure changes in the level and severity of depression symptoms. The form includes 21 self-evaluation statements with 4-point Likert-type responses. Total points range from 0-63. A threshold value of 17 points has been accepted for validity and reliability in Turkish. High total points indicate a high risk of depression.

The Beck Anxiety Inventory (Beck-A): The original measurement scale form was developed by Beck, et al. ${ }^{15}$. Adaptation to Turkish was made by Ulusoy, et al. ${ }^{16}$. It is used to determine the level of anxiety and distribution and severity of symptoms. The form consists of 21 self-evaluation statements and total points range from 0-63. High total points indicate a high level of anxiety.

The Hospital Anxiety and Depression Scale (HAD): The original form was developed by Zigmond et al ${ }^{17}$. It has been tested for validity and reliability in Turkish ${ }^{18}$. It consists of 14 self-evaluation questions in subscales of anxiety and depression. It is used to determine the risk of anxiety and depression and measure the change in their levels and severity. High subscale total points show a high risk of anxiety and depression.

Short Form-36 (SF-36): The original form was developed by Ware and Sherbourne ${ }^{19}$. It has been tested for validity and reliability in Turkish ${ }^{20}$. It was developed to measure the quality of life of patients with physical diseases in particular, although it has also been used successfully for those with psychiatric diseases and for healthy subjects. It is a self-assessment scale of 36 items in 8 dimensions of health such as physical functioning, bodily pain, role limitations due to physical health problems, role limitations due to personal or emotional problems, emotional well-being, social functioning, energy/fatigue and general health perceptions. The scoring of the subscales range from 0-100 and high points indicate a good health status.

\section{Statistical Analyses}

In the evaluation of descriptive statistics, percentages derived from the scores of the scales were stated arithmetically as mean \pm standard deviation (minimum-maximum). Data defined to have normal distribution in the scale were evaluated with the post hoc corrected ANOVA test and a value of $\mathrm{p}<0.05$ was accepted as statistically significant. Data without normal distribution were first analysed with the Kruskal Wallis test, and the significance level in that test was placed at $\mathrm{p}<0.05$.

Following analysis of the three groups, to determine in which group the difference arose, the Bonnferroni corrected Mann Whitney $U$ test was used, and the significance level was set by dividing by the number of comparisons, $p=0.05 / 3=0.0167$. The data determined by the scoring were compared with the Chi-square test, and statistical significance was accepted as $p<0.05$. The relationship between the caregiving burden of diabetic and psychiatric patients'caregivers and the duration of care-giving (years), Beck anxiety, Beck depression, HAD anxiety, HAD depression scale total points and the physical function (Pf), physical role difficulties (Rp), pain (Bp), vitality (Vt), social function (Sf), emotional role difficulties (Re) and mental health $(\mathrm{Mh})$ points of the SF-36 subscales, were evaluated with the Spearman correlation test and statistical significance was set as $\mathrm{p}<0.05$. 


\section{RESULTS}

The study was comprised of 90 care-givers with a mean age of $44.67 \pm 12.04$ years. Various sociodemographic characteristics associated with the participants that could be of importance in the study are shown in Table 1.

\section{Table 1. Sociodemographic characteristics of the participants}

\begin{tabular}{|c|c|c|c|}
\hline \multicolumn{2}{|c|}{ Sociodemographic Characteristics } & \multirow{2}{*}{$\frac{\mathbf{n}}{42}$} & \multirow{2}{*}{$\begin{array}{c}\% \\
46.7\end{array}$} \\
\hline Gender $(n=90)$ & Male & & \\
\hline & Female & 48 & 53.3 \\
\hline \multirow[t]{3}{*}{ Marital status (n=90) } & Single & 10 & 11.1 \\
\hline & Married & 74 & 8.2 \\
\hline & Widowed & 6 & 6.7 \\
\hline \multirow[t]{3}{*}{ Educational level $(\mathrm{n}=90)$} & Illiterate & 29 & 32.2 \\
\hline & Primary school & 44 & 48.9 \\
\hline & High school and above & 17 & 18.9 \\
\hline \multirow[t]{3}{*}{ Monthly income (n=90) } & 0-799 TL & 31 & 34.4 \\
\hline & 800-1499 TL & 34 & 37.8 \\
\hline & 1500 and above & 2 & 27.8 \\
\hline \multirow[t]{3}{*}{ Relationship to patient $(\mathrm{n}=90)$} & $1^{\text {st }}$ degree relative & 66 & 73.4 \\
\hline & $2^{\text {nd }}$ or $3^{\text {rd }}$ degree relative & 12 & 13.3 \\
\hline & Spouse & 12 & 13.3 \\
\hline \multirow[t]{3}{*}{ Employment status ( $\mathrm{n}=90)$} & Unemployed & 31 & 34.4 \\
\hline & Housewife & 24 & 26.7 \\
\hline & Employed & 35 & 38.9 \\
\hline \multirow[t]{2}{*}{ Physical disease $(n=90)$} & No & 63 & 70.0 \\
\hline & Yes & 27 & 30.0 \\
\hline \multirow[t]{2}{*}{ Psychiatric disease $(n=90)$} & No & 81 & 90.0 \\
\hline & Yes & 9 & 10.0 \\
\hline \multirow[t]{2}{*}{ Help with the care given at home $(n=90)$} & No & 73 & 81.1 \\
\hline & Yes & 17 & 18.9 \\
\hline \multirow[t]{2}{*}{ Patient gender $(\mathrm{n}=90)$} & Male & 61 & 67.8 \\
\hline & Female & 29 & 32.2 \\
\hline \multirow[t]{3}{*}{ Patient education level $(\mathrm{n}=90)$} & Illiterate & 36 & 40.0 \\
\hline & Primary school & 42 & 46.7 \\
\hline & High school and above & 12 & 13.3 \\
\hline
\end{tabular}

The findings obtained from the comparison between the caregivers of the diabetic foot patients (Group 1), the psychotic disorder patients (Group 2) and the inguinal hernia patients (Group 3 -control) in respect to sociodemographic characteristics and the total points of the scales are shown in Tables 2 and 3. The diabetic foot group was observed to be predominantly female (80\%).

The burden of care of the caregivers to diabetic foot patients was found to be statistically significantly higher than that of the control group ( $\mathrm{p}<0.001$ ) but no significant difference was found in comparison with the psychotic disorder patient group. The points of the Beck depression $(p<0.001)$, Beck anxiety $(p<0.001)$, HAD anxiety $(p<0.001)$ and HAD depression ( $p=0.001)$ scales were found to be statistically significantly high compared to those of the psychiatric disorder and control groups. The points of the SF-36 subscales of physical role difficulties $(\mathrm{p}<0.001)$, vitality, $(\mathrm{p}<0.001)$, emotional role difficulties $(\mathrm{p}<0.001)$ and mental health $(\mathrm{p}<0.001)$ were found to be statistically significantly low compared to those of the psychiatric and control groups. In each group, the relationship was examined between the care-giver's points and the other scale points and various characteristics such as age and duration of care. The significant relationships are shown in Table 4.

Unlike in the other groups, a statistically significant relationship was determined in the diabetic foot group between the caregiver's burden and the duration of care $(p=0.020, r=0.421)$. 
Table 2. Comparison of the study groups according to some sociodemographic characteristics *

\begin{tabular}{|c|c|c|c|c|c|}
\hline Sociodemographic & aracteristics & $\begin{array}{c}\text { Group } 1 \\
(n=30)\end{array}$ & $\begin{array}{c}\text { Group } 2 \\
(n=30)\end{array}$ & $\begin{array}{c}\text { Control } \\
(n=30)\end{array}$ & $\begin{array}{c}\mathbf{P} \\
\mathbf{Y}^{2}\end{array}$ \\
\hline Gender & Male & $6(20)$ & $12(40)$ & $24(80)$ & $<0.001$ \\
\hline & Female & $24(80)$ & $18(60)$ & $6(20)$ & 22.5 \\
\hline Marital status & Single & $5(16.7)$ & $1(3.3)$ & $4(13.3)$ & 0.435 \\
\hline & Married & $23(76.7)$ & $26(86.7)$ & $25(83.4)$ & 3.7 \\
\hline & Widowed & $2(6.6)$ & $3(10)$ & $1(3.3)$ & \\
\hline Relationship to patient & $1^{\text {st }}$ degree relative & $16(53.3)$ & $27(90)$ & $23(76.7)$ & 0.029 \\
\hline & $2^{\text {nd }}$ or $3^{\text {rd }}$ degree relative & $7(23.3)$ & $2(6.7)$ & $3(10)$ & \\
\hline & Spouse & $7(23.3)$ & $1(3.3)$ & $4(13.3)$ & 17.6 \\
\hline Education level & Illiterate & $5(16.7)$ & $22(73.3)$ & $2(6.7)$ & $<0.001$ \\
\hline & Primary school & $20(66.7)$ & $3(10)$ & $21(70)$ & \\
\hline & High school and above & $5(16.7)$ & $5(16.7)$ & $7(23.3)$ & 42.6 \\
\hline Employment status & Unemployed & $2(6.7)$ & $22(73.3)$ & $7(23.3)$ & $<0.001$ \\
\hline & Housewife & $16(53.3)$ & $2(6.7)$ & $6(20)$ & 48.3 \\
\hline & Employed & $12(40)$ & $6(20)$ & $17(56.7)$ & \\
\hline Monthly income & 0-799 TL & $13(43.3)$ & $6(20)$ & $12(40)$ & 0.080 \\
\hline & 800-1499 TL & $8(26.7)$ & $12(40)$ & $14(46.7)$ & \\
\hline & 1500 and above & $9(30)$ & $12(40)$ & $4(13.3)$ & 8.3 \\
\hline Physical disease $(n=90)$ & No & $22(73.3)$ & $14(46.7)$ & $27(90)$ & 0.010 \\
\hline & Yes & $8(26.7)$ & $16(53.3)$ & $3(10)$ & 13.6 \\
\hline Psychiatric disease $(n=90)$ & No & $28(93.3)$ & $23(76.7)$ & $30(100)$ & $* *$ \\
\hline & Yes & $2(6.7)$ & $7(23.3)$ & $0(0.0)$ & \\
\hline Help with the care given at home $(n=90)$ & No & $22(73.3)$ & $23(76.7)$ & $28(93.3)$ & 0.106 \\
\hline & Yes & $8(26.7)$ & $7(23.3)$ & $2(6.7)$ & 4.4 \\
\hline Patient gender $(n=90)$ & Male & $16(53.3)$ & $21(70)$ & $24(80)$ & 0.083 \\
\hline & Female & $14(46.7)$ & $9(30)$ & $6(20)$ & 4.9 \\
\hline
\end{tabular}

*Chi-square test was used. Column percentage was taken (significance level $\mathrm{p}<0.05$ ) $* *$ Chi-square test not applied 
Table 3. Comparison of the study groups according to sociodemographic characteristics and scale points

\begin{tabular}{|c|c|c|c|c|}
\hline & $\begin{array}{c}\text { Control }(\mathrm{n}: 30) \\
\text { mean } \pm \text { SD } \\
(\min -\mathbf{m a x})\end{array}$ & $\begin{array}{c}\text { Group } 1(\mathrm{n}: 30) \\
\text { Mean } \pm \text { SD } \\
(\text { min-max })\end{array}$ & $\begin{array}{c}\text { Group } 2(\mathrm{n}: 30) \\
\text { Mean } \pm \text { SD } \\
(\min -\mathbf{m a x})\end{array}$ & $\begin{array}{c}P \text { and } \\
\text { value }\left(X^{2} / t \text { or } F\right)\end{array}$ \\
\hline Age & $\begin{array}{l}42.3 \pm 11.1 \\
(23.0-63.0)\end{array}$ & $\begin{array}{l}43.1 \pm 12.5 \\
(19.0-64.0)\end{array}$ & $\begin{array}{l}48.6 \pm 11.9 \\
(20.0-64.0)\end{array}$ & $\begin{array}{l}0.075 * * \\
X^{2}=5.1\end{array}$ \\
\hline No of children & $\begin{array}{l}2.0 \pm 1.6 \\
(0.0-6.0)\end{array}$ & $\begin{array}{l}2.4 \pm 1.9 \\
(0.0-8.0)\end{array}$ & $\begin{array}{c}2.7 \pm 1.4 \\
(0.0-6)\end{array}$ & $\begin{array}{l}0.161 * * \\
X^{2}=2.2\end{array}$ \\
\hline Duration of care-giving (yrs) & - & $\begin{array}{c}3.1 \pm 3.3 \\
(1.0-17.0)\end{array}$ & $\begin{array}{l}14.2 \pm 8.6 \\
(1.0-30.0)\end{array}$ & $\begin{array}{c}<0.001 * * * \\
\mathrm{t}=-7.4 \mathrm{SD}=31.6\end{array}$ \\
\hline Age of patient being cared for (yrs) & $\begin{array}{l}49.6 \pm 20.6 \\
(18.0-81.0)\end{array}$ & $\begin{array}{l}66.6 \pm 13.7 \\
(22.0-90.0)\end{array}$ & $\begin{array}{c}40.8 \pm 1.6 \\
(26.0-71.0)\end{array}$ & $\begin{array}{l}<0.001 * * \\
\mathrm{X}^{2}=21.8\end{array}$ \\
\hline Beck depression scale & $\begin{array}{c}5.6 \pm 6.2 \\
(0.0-28.0)\end{array}$ & $\begin{array}{c}19.1 \pm 12.9 \\
(2.0-49)\end{array}$ & $\begin{array}{c}7.2 \pm 7.0 \\
(0.0-32.0)\end{array}$ & $\begin{array}{c}<0.001 * * \\
\mathrm{X}^{2}=\end{array}$ \\
\hline Beck anxiety & $\begin{array}{c}5.7 \pm 6.0 \\
(0.0-20.0)\end{array}$ & $\begin{array}{c}19.2 \pm 11.7 \\
(1.0-51.0)\end{array}$ & $\begin{array}{l}9.0 \pm 13.1 \\
(0.0-26.0)\end{array}$ & $\begin{array}{l}<0.001 * * \\
\mathrm{X}^{2}=25.7\end{array}$ \\
\hline Care-giving burden & $\begin{array}{c}34.5 \pm 8.4 \\
(23.0-60.0)\end{array}$ & $\begin{array}{l}47.1 \pm 14.5 \\
(27.0-72.0)\end{array}$ & $\begin{array}{l}49.0 \pm 13.1 \\
(27.0-73.0)\end{array}$ & $\begin{array}{l}<0.001 * \\
\mathrm{~F}=12.35\end{array}$ \\
\hline HAD anxiety & $\begin{array}{c}5.6 \pm 3.5 \\
(0.0-18.0)\end{array}$ & $\begin{array}{c}9.4 \pm 4.2 \\
(1.0-19.0)\end{array}$ & $\begin{array}{c}5.7 \pm 4.7 \\
(0.0-17.0)\end{array}$ & $\begin{array}{l}<0.001 * * \\
\mathrm{X}^{2}=16.1\end{array}$ \\
\hline HAD depression & $\begin{array}{c}6.3 \pm 3.9 \\
(0.0-14.0)\end{array}$ & $\begin{array}{c}9.8 \pm 4.7 \\
(0.0-20.0)\end{array}$ & $\begin{array}{c}5.2 \pm 3.9 \\
(0.0-16.0)\end{array}$ & $\begin{array}{l}0.001^{*} \\
\mathrm{~F}=9,69\end{array}$ \\
\hline Pf points & $\begin{array}{l}71.8 \pm 25.4 \\
(5.0-100.0)\end{array}$ & $\begin{array}{c}62.1 \pm 35.3 \\
(0.00-100.0)\end{array}$ & $\begin{array}{c}76.0 \pm 21.9 \\
(25.0-100.0)\end{array}$ & $\begin{array}{l}0.500 * * \\
\mathrm{X}^{2}=1.3\end{array}$ \\
\hline Rp points & $\begin{array}{l}62.5 \pm 39.3 \\
(0.0-100.0)\end{array}$ & $\begin{array}{l}25.8 \pm 33.7 \\
(0.0-100.0)\end{array}$ & $\begin{array}{l}77.5 \pm 34.9 \\
(0.0-100.0)\end{array}$ & $\begin{array}{l}<0.001 * * \\
X^{2}=24.6\end{array}$ \\
\hline Bp point & $\begin{array}{l}55.6 \pm 21.1 \\
(20.0-90.0)\end{array}$ & $\begin{array}{l}53.0 \pm 17.6 \\
(20.0-90.0)\end{array}$ & $\begin{array}{l}59.0 \pm 27.5 \\
(20.0-90.0)\end{array}$ & $\begin{array}{l}0.728 * * \\
\mathrm{X}^{2}=0.6\end{array}$ \\
\hline Vt points & $\begin{array}{c}62.0 \pm 19.3 \\
(20.0-100.0)\end{array}$ & $\begin{array}{l}39.1 \pm 18.8 \\
(10.0-80.0)\end{array}$ & $\begin{array}{c}53.6 \pm 23.4 \\
(10.0-100.0)\end{array}$ & $\begin{array}{l}<0.001 * \\
\mathrm{~F}=9.37\end{array}$ \\
\hline Sf points & $\begin{array}{c}69.5 \pm 24.2 \\
(25.0-100.0)\end{array}$ & $\begin{array}{c}60.4 \pm 19.7 \\
(12.5-100.0)\end{array}$ & $\begin{array}{c}65.8 \pm 22.7 \\
(25.0-100.0)\end{array}$ & $\begin{array}{c}0.369 * * \\
\mathrm{X}^{2}=0.3\end{array}$ \\
\hline Re points & $\begin{array}{l}58.8 \pm 37.8 \\
(0.0-100.0)\end{array}$ & $\begin{array}{l}20.0 \pm 28.5 \\
(0.0-100.0)\end{array}$ & $\begin{array}{l}71.1 \pm 37.8 \\
(0.0-100.0)\end{array}$ & $\begin{array}{l}<0.001 * * \\
\mathrm{X}^{2}=25.6\end{array}$ \\
\hline Mh points & $\begin{array}{l}64.2 \pm 19.7 \\
(16.0-96.0)\end{array}$ & $\begin{array}{l}44.4 \pm 17.9 \\
(16.0-92.0)\end{array}$ & $\begin{array}{c}57.8 \pm 17.2 \\
(24.0-100.0)\end{array}$ & $\begin{array}{l}<0.001 * * \\
X^{2}=17.4\end{array}$ \\
\hline
\end{tabular}

*ANOVA and Bonferroni Post-Hoc test. **Kruskall Wallis test. ***Control group(care-givers to patients with inguinal hernia) excluded from test, Mann Whitney U test applied.

HAD: Hospital Anxiety and Depression, Pf: physical functioning, Rp: role limitations due to physical health problems, Bp: bodily pain, VT: vitality, Sf: social functioning, Re: role limitations due to emotional problems, Mh: mental health 
Table 4. Correlations of the care-giving burden and some parameters

\begin{tabular}{|c|c|c|c|}
\hline Variable & $\begin{array}{c}\text { Control (n:30) } \\
(\mathbf{r}, \mathbf{p})\end{array}$ & $\begin{array}{c}\text { Group } 1(n: 30) \\
(r, p)\end{array}$ & $\begin{array}{c}\text { Group } 2(n: 30) \\
(r, p)\end{array}$ \\
\hline Duration of care (yrs) & NS & $\begin{array}{l}\mathrm{r}=0.421 \\
\mathrm{p}=0.020\end{array}$ & NS \\
\hline Age of care-giver & $\begin{array}{c}r=-0.421 \\
p=0.021\end{array}$ & NS & $\begin{array}{l}r=0.443 \\
p=0.014\end{array}$ \\
\hline Age of patient (yrs) & NS & NS & $\begin{array}{l}r=-0.387 \\
p=0.035\end{array}$ \\
\hline Beck Anxiety points & NS & $\begin{array}{l}r=0.426 \\
p=0.019\end{array}$ & NS \\
\hline Beck Depression points & NS & NS & $\begin{array}{l}\mathrm{r}=0.524 \\
\mathrm{p}=0.003\end{array}$ \\
\hline HAD anxiety points & NS & $\begin{array}{l}\mathrm{r}=0.039 \\
\mathrm{p}=0.033\end{array}$ & $\begin{array}{l}\mathrm{r}=0.446 \\
\mathrm{p}=0.013\end{array}$ \\
\hline HAD depression points & $\begin{array}{l}\mathrm{r}=0.459 \\
\mathrm{p}=0.011\end{array}$ & NS & $\begin{array}{l}\mathrm{r}=0.403 \\
\mathrm{p}=0.027\end{array}$ \\
\hline Pf points & NS & NS & $\begin{array}{l}r=-0.460 \\
p=0.011\end{array}$ \\
\hline Rp points & NS & NS & NS \\
\hline Bp points & NS & NS & $\begin{array}{l}r=0.487 \\
p=0.006\end{array}$ \\
\hline Vt points & NS & NS & $\begin{array}{l}r=-0.675 \\
p<0.001\end{array}$ \\
\hline Sf points & NS & NS & $\begin{array}{l}r=-0.626 \\
p=0.030\end{array}$ \\
\hline Re points & NS & NS & $\begin{array}{l}r=-0.397 \\
p=0.030\end{array}$ \\
\hline Mh points & $\begin{array}{l}r=-0.411 \\
p=0.024\end{array}$ & NS & $\begin{array}{l}r=-0.673 \\
p<0.001\end{array}$ \\
\hline
\end{tabular}

NS=not significant

Spearman Correlation test was applied.

\section{DISCUSSION}

In parallel with increasing mean survival rates in chronic diseases, the increasing complications bring a greater burden of care to all sections of society. Following the management of the acute phase of the disease in the hospital, there is a significant need for care to protect the levels of health in patients when they are discharged.

When the sociodemographic characteristics of the caregivers in this study were compared, it was observed that the caregivers of patients with diabetic foot ulcers were predominantly female (mainly housewives) and those of the control group were mostly male. In Turkish culture, in emergency situations and situations requiring physical strength, the man of the family is expected to intervene first. When it is considered that the inguinal hernia patients are brought to hospital with a sudden onset of pain or complaints and are discharged after a short period of hospitalisation, dealing with the process of hospital presentation and care procedures can be evaluated as situations appropriate to the role of the male in the family in Turkish culture. Throughout the world, for reasons of various ideologies, females are generally thought of as those giving care and in some countries, giving care is even accepted as a woman's duty according to the family rules ${ }^{6}$. In Turkish society, caregiving is also perceived as a duty assigned to women.

The fact that the care-givers of patients with psychotic disorders were predominantly first-degree relatives was viewed as logical considering that more distant relatives and others would avoid looking after these kinds of patients in their own home due to concerns of uncontrolled behaviour being a bad example to their own spouse and/or children. In contrast, in cases where the elderly require care such as for diabetic foot, care is given by distant relatives who have them stay in their homes. In Turkish culture, this task of caring, in terms of teaching children to look after the elderly is evaluated as a behaviour which will be appreciated. Theoretically these patients do not have the potential to cause damage around them.

When the educational levels of the caregivers were assessed, it was observed that the diabetic group's results were similar to those of the control group in that most had completed primary school education. There were significantly more illiterates in the psychosis group. Diabetes is known to be related to diet and lifestyle, therefore in educated, working and high income sections of a developed society, increased calorie intake and a sedentary lifestyle are known to result in a high incidence. In the structure of our country, as the result of an educated individual improving their sociocultural level, the educational level of the care-giver was found to be high due to the most frequent caregivers being first-degree relatives. 
That a significant proportion of the caregivers to patients with psychotic disorders were unemployed could be connected to the low level of education and/or the caregiver having left employment due to problems of bad time allocation, poor effort or low energy for caregiving this however, was not indicated in the investigation. In literature, it has been reported that caregivers of psychiatric patients are usually obliged to take leave from paid employment or choose not to work full-time. Therefore they do not fulfill their economic or career potential ${ }^{4}$. By not meeting employers' expectations, those individuals not fulfilling their potential will inevitably remain unemployed. Thus, the findings of this study, in which more unemployed caregivers are in the psychotic disorder group, are supported by reports in literature.

When the income levels of the care-givers were examined, an incongruity with the previous paragraph was observed. Despite lower levels of education and higher rates of unemployment, the income level of the care-givers in the psychotic patients group was observed to be high. This can be explained by the healthcare policies of Turkey. Unemployment benefit is paid, and those caring for a dependent patient at home are also paid a caregiver's allowance. Therefore, this group can obtain a higher level of monthly income.

In the evaluation of the caregivers in respect to their own physical or psychiatric health, the duration of care may be an indicator in the diabetic group. Whereas the duration of care in the diabetic group was a reason for burnout, it remained at a relatively low limit and no statistically significant difference was determined, when the duration of the psychosis group was taken into consideration.

While no statistically significant difference was found between the diabetic foot and the psychosis groups in respect to the burden of care, both groups were found to be at high levels of burden compared to the control group. In studies in literature which have compared the caregiver's burden in physical versus psychological diseases, it was found that those caring for psychologically ill patients were under a greater burden. It has been claimed that the increase in the caregiving burden could be due to problems such as the inappropriate behaviours of psychiatric patients, mood changes, attacks of anger and sleep disorders ${ }^{5,6}$. Parallel to several studies in literature, a difference was observed in the current study between the psychosis group and the control group, but no difference was determined when compared to the diabetic group, as the caregivers of the diabetic group were also seen to be under a severe burden of caregiving. Pervious studies reported that low levels of education were associated with an increased burden of caregiving ${ }^{21}$. Supporting that finding, the high number of illiterate caregivers in the diabetic group of the current study could be found to contribute to the high level of the burden of care.

Being of female gender has been reported to be related to a high burden of caregiving ${ }^{22}$. In the current study, the fact that the caregivers in the diabetic group were predominantly female was thought to play a role in the high level of the burden of caregiving.

When the anxiety and depression scales were evaluated, the caregivers of the diabetic group were observed to have higher levels compared to both the psychosis group and the control group. This would seem to be due to the majority of the group in the current study being housewives and as such having to live together with an elderly person requiring care at home, and losing the opportunity to go out of home. They remained isolated from social life which caused a decrease in quality of life and increased anxiety and depression levels in addition to the high burden of care. As diabetic foot patients are older it is thought that difficulties in conformity to treatment could also be a reason for increased anxiety.

Caregivers of schizophrenia patients have been reported to experience physical and psychological health problems associated with the long-term effects of stress ${ }^{23}$. In the current study, although physical and psychological diseases were determined at a higher rate in the pyschosis group than in the diabetic foot group, the anxiety and depression scale scores were lower. This can be associated with the caregivers of psychotic patients having become accustomed to living with somebody with a chronic illness, and having learned the importance of regular treatment both for themselves and for the patient. Although this is is not supported by studies in literature, our clinical practice has shown that the majority of caregivers of psychotic patients are themselves receiving supportive treatment.

While the burden of caregiving in the diabetic group was found to be no different from that of the psychosis group, the anxiety and depression levels were higher and the quality of life was found to be lower. This can be associated with the caregivers not accessing information services and the necessary treatment for their own physical and psychological health problems, as it is mainly housewives who are caring for diabetic foot patients. In fact, the necessary education on this subject has not yet been organised in our country, corresponding with the increasing numbers of patients with diabetic foot ulcers in recent years. This situation arises from both patients and their caregivers not receiving the required education on dealing with the problems they experience.

When the characteristics related to the care-giving burden were examined in the diabetic group, the duration of care-giving was found to be significant. This finding is supported by studies which have found a correlation between the care-giving burden and the duration of the disease ${ }^{5,22}$. When treatment is extended for patients with diabetic foot ulcers, the caregivers should be referred to the relevant departments for support.

When the characteristics related to the caregiving burden were examined in the psychosis group, a positive correlation was found with the age of the caregiver and a negative correlation was found with the age of the patient. The positive relationship determined in this study between the caregiving burden and the age of the caregiver is supported by previous studies which have found that as the age of the caregiver increased so the caregiving burden increased ${ }^{5,24}$. The increase in the caregiving burden has been reported to be associated with additional responsibilities for the caregivers, patients' families and patients' own health and with increasing age The caregiver is less able to deal with physical and psychological problems ${ }^{5}$. 
In the current study, it was also considered that the increased caregiving burden associated with an increased age of the caregiver could be due to an older caregiver having less physical and psychological resistance and therefore an increase in their own illnesses. The negative correlation between patient age and the caregiving burden is consistent with data in literature on this subject ${ }^{25}$. In Turkish society, while the elderly with age-related diseases are accepted as family members, the acceptance of disease in the young is known to be more difficult ${ }^{26}$. In the current study, the finding of a decreasing caregiving burden as the patient age increases can be interpreted as difficulties accepting the disease and treatment in the early stages of psychotic diseases and behavioural problems continuing until the appropriate treatment is organised.

Although this study had some limitations in that the gender, educational levels and occupations of the caregiver groups were not homogenous, the data can be considered to be a timely reminder to clinicians that potential problems should not be ignored in the caregivers of patients with chronic diseases such as psychotic disorders and diabetic foot. If clinicians address this issue, they can help caregivers who are at risk for high caregiver burden by consulting them to a psychiatrist. Psycholog interviews or group therapy can also be useful for most of the cases.

By overcoming the limitations on this subject, further studies regarding the care of patients with chronic diseases would be able to provide more comprehensive information on the subject of the caregiver's and the patient's anticipated problems. Starting with the assumption that those caring for patients with chronic diseases are healthy individuals and then protecting the physical and psychological health of this group is just as important as the treatment of the patients.

Acknowledgements: We thank the staff of the Hitit University Education and Research Hospital's Surgery Ward and Community Mental Health Center.

Conflict of interest: none

Funding: none

\section{REFERENCES}

1. Archbold PG, Stewart BJ, Greenlick MR, et al. Mutuality and preparedness as predictors of caregiver role strain. Research in nursing \& health. 1990;13(6):375-384.

2. Silver HJ, Wellman NS. Family caregiver training is needed to improve outcomes for older adults using home care technologies. Journal of the American Dietetic Association. 2002;102(6):831-836.

3. Kasuya RT, Polgar-Bailey P, Takeuchi R. Caregiver burden and burnout. A guide for primary care physicians. Postgraduate medicine. 2000;108(7):119-123.

4. Atagün Mİ, Balaban ÖD, Atagün Z, et al. Kronik hastalıklarda bakım veren yükü. Psikiyatride Güncel Yaklaşımlar 2011;3(3):513-552.

5. Ampalam P, Gunturu S, Padma V. A comparative study of caregiver burden in psychiatric illness and chronic medical illness. Indian journal of psychiatry. 2012;54(3):239-243.

6. Gupta A, Sharma R. Burden and coping of caregivers of physical and mental illnesses. Delhi Psychiatry Journal. 2013;16(2):367374.

7. Magliano L, Fiorillo A, De Rosa C, et al. Family burden in long-term diseases: a comparative study in schizophrenia vs. physical disorders. Social science \& medicine. 2005;61(2):313-322.

8. Awad AG, Voruganti LN. The burden of schizophrenia on caregivers: a review. PharmacoEconomics. 2008;26(2):149-162.

9. Arslantaş H, Adana F. The Burden of Schizophrenia on Caregivers. Current Approaches in Psychiatry. 2011;3(2):251-277.

10. Brod M. Quality of life issues in patients with diabetes and lower extremity ulcers: patients and care givers. Quality of life research : an international journal of quality of life aspects of treatment, care and rehabilitation. 1998;7(4):365-372.

11. Zarit SH, Reever KE, Bach-Peterson J. Relatives of the impaired elderly: correlates of feelings of burden. The Gerontologist. 1980;20(6):649-655.

12. Özlü A, Yıldız M, Aker T. Zarit Bakıcı Yük Ölçeğinin şizofreni hasta yakınlarında geçerlilik ve güvenilirlik çalışması. Nöropsikiyatri Arşivi. 2009;46:38-42.

13. Beck AT. An inventory for measuring depression. Archives General Psychiatry. 1961;4:561-571.

14. Hisli N. Beck Depresyon Envanterinin üniversite öğrencileri için geçerliliği, güvenilirliği. Psikoloji Dergisi. 1989;7:3-13.

15. Beck AT, Epstein N, Brown G, et al. An inventory for measuring clinical anxiety: psychometric properties. Journal of consulting and clinical psychology. 1988;56(6):893-897.

16. Ulusoy M. Beck Anksiyete Envanteri: Geçerlik ve güvenirlik çalışması. Bakırköy Ruh ve Sinir Hastalıkları Hastanesi Istanbul: Bakırköy Ruh ve Sinir Hastalıkları Hastanesi. Istanbul 1993.

17. Zigmond AS, Snaith PR. The hospital anxiety and depression scale. Acta Psychiatrica Scandinavica. 1983;67:361-370.

18. Aydemir Ö, Güvenir T, Küey L, et al. Hastane Anksiyete ve Depresyon Ölçeği Türkçe formunun geçerlilik ve güvenilirliği. Türk Psikiyatri Dergisi. 1977;8:280-287. 
19. Ware JE, Sherbourne CD. The MOS 36-item short-form health survey (SF-36). I. Conceptual framework and item selection. Medical care. 1992;30(6):473-483.

20. Koçyiğit H, Aydemir Ö, Ölmez N, et al. Kısa Form-36 (KF-36)'nın Türkçe versiyonunun güvenilirliği ve geçerliliğii. İlaç ve Tedavi Dergisi. 1999;12:102-106.

21. Ukpong DI. Demographic factors and clinical correlates of burden and distress in relatives of service users experiencing schizophrenia: a study from south-western Nigeria. International journal of mental health nursing. 2006;15(1):54-59.

22. Gulseren L, Cam B, Karakoc B, et al. [The perceived burden of care and its correlates in schizophrenia]. Turk psikiyatri dergisi = Turkish journal of psychiatry. 2010;21(3):203-212.

23. Şengün F. Şizofreni hastasına bakım verenlerin ruhsal sağlık durumlarını etkileyen etmenlerin incelenmesi (Psikiyatri hemşireliği yüksek lisans tezi). İzmir, Dokuz Eylül Üniversitesi 2007.

24. Caqueo-Urizar A, Gutierrez-Maldonado J. Burden of care in families of patients with schizophrenia. Quality of life research : an international journal of quality of life aspects of treatment, care and rehabilitation. 2006;15(4):719-724.

25. McDonell MG, Short RA, Berry CM, et al. Burden in schizophrenia caregivers: impact of family psychoeducation and awareness of patient suicidality. Family process. 2003;42(1):91-103.

26. Karlikaya G, Yuksek G, Varlibas F, et al. Caregiver Burden In Dementia: A Study In The Turkish Population. The Internet Journal of Neurology. 2004;4:2. 